\title{
Detection of Low Salinity Groundwater Seeping into the Eastern Laizhou Bay (China) with the Aid of Landsat Thermal Data
}

\author{
Qianguo Xing ${ }^{\dagger *}$, Federica Braga ${ }^{*}$, Luigi Tosi ${ }^{\ddagger}$, Mingjing Lou ${ }^{\dagger}$, Luca Zaggia ${ }^{*}$, Pietro Teatini ${ }^{\ddagger \#}$, \\ Xuelu Gao ${ }^{\dagger}$, Liangju Yu ${ }^{\dagger}$, Xiaohu Wen ${ }^{\dagger}$, and Ping Shi ${ }^{\dagger}$ \\ Yantai Institute of Coastal Zone Research \\ Chinese Academy of Sciences \\ Yantai, Shandong 264003, P. R. China \\ ${ }^{\ddagger}$ Institute of Marine Sciences \\ National Research Council of Italy \\ Arsenale Tesa 104, Castello 2737f, \\ Venezia, Italy \\ ${ }^{\#}$ Dept of Civil, Environmental \\ and Architectural Engineering, \\ University of Padova \\ Via Trieste 63, Padova, Italy
}

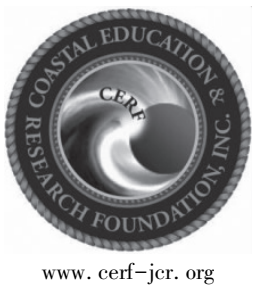

www. cerf-jcr. org

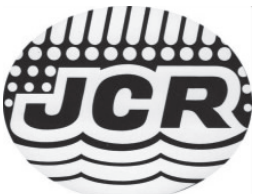

www. JCRonline. org

\section{ABSTRACT}

Xing, Q. G.; Braga, F.; Tosi, L.; Lou, M. J.; Zaggia, L.; Teatini, P.; Gao, X. L.; Yu, L. J.; Wen, X. H., and Shi, P., 2016. Detection of low salinity groundwater seeping into the Eastern Laizhou Bay (China) with the aid of Landsat Thermal Data. In: Harff, J. and Zhang, H. (eds. ), Environmental Processes and the Natural and Anthropogenic Forcing in the Bohai Sea, Eastern Asia. Journal of Coastal Research, Special Issue, No. 74, pp. 149-156. Coconut Creek (Florida), ISSN 0749-0208.

Low-salinity groundwater storages beneath the sea bottom and submarine groundwater discharges (SGD) are of great importance in environmental management and the use of coastal water resources. A preliminary hydromorpho- geologic analysis allows for considering the presence of low-salinity groundwater in the offshore of the Laizhou Bay (Southern Bohai Sea, China). In order to detect the potential SGD, the analysis of the Sea Surface Temperature (SST) anomalies was carried out using Landsat thermal images acquired in the seasons characterised by the largest difference in temperature between seawater and groundwater. At the nearshore scale, patchy cold water anomalies occur approximately in the same positions along the intertidal zone of the Southern bay, where the unconfined aquifer discharges, independently of tide conditions. At the embayment scale, cold water anomalies spread out in the Eastern Laizhou Bay where the confined aquifer is likely exposed. Salinity and temperature measured in surficial waters of the eastern Laizhou Bay support the hypothesis of SGD, which can be derived from remote sensing images; the occurrence of macroalgal blooms might also be the consequence of the SGD-enhanced nutrient supply. This work pointed out the need of future oceanographic and groundwater flow modeling along with long-term monitoring of processes associated with the suspected SGD. The outcomes of this preliminary study will be of great help to direct effective in-situ investigations aimed at quantifying the volumes of SGD and to simulate coupled groundwater/surface-water flow.

ADDITIONAL INDEX WORDS: Submarine groundwater discharge, sea surface temperature, thermal infrared remote sensing, Landsat, the Laizhou Bay, the Bohai Sea.

\section{INTRODUCTION}

Groundwater plays an important role in the coastal environment: it provides baseflow in rivers and estuaries, reduces salinities and provides nutrients to specialized coastal wetland wildlife habitats. The dissolved chemicals discharged by the submarine groundwater, often undetected, can be pollutant source causing eutrophication and triggering nuisance algal blooms ( Rao and Charette, 2012). It is also fundamental for the development of welfare in coastal areas whether it is used for drinking purposes or in agricultural and industrial activities. Around the world, following the trend of urbanization, coastal groundwater resources are under increasing pressure due to the intensification of human activities, development of industrial and urban centres, as well as to climate changes.

The presence of offshore low-salinity groundwater reserves below continental shelves is a global occurrence (Post et al.,

DOI: 10.2112/SI74-014. 1 received ( 27 January 2015); accepted in revision (2 July 2015).

"Corresponding author: qgxing@ yic. ac.cn

${ }^{\circ}$ Coastal Education and Research Foundation, Inc. 2016
2013). They occur at nearshore, embayment and shelf scales (Bratton, 2010) , depending on their genesis and on hydro- morpho- geologic setting of the inland and the sea sectors. Lowsalinity palaeo-water beneath the continental shelf is generally groundwater of confined aquifers trapped during sea level lowstands, while modern water seeps from the intertidal zone are groundwater of unconfined and/or semi-confined aquifer systems extending seaward.

It is important to investigate the potential occurrence of offshore low-salinity groundwater for a series of reasons. Firstly, the identification of new strategic low-salinity water reserves becomes fundamental in the expected future scenarios of water scarcity (IPCC, 2014; Jackson et al., 2001; Plain Blue, 2008 ). Furthermore, the quantification of groundwater exchanges in the coastal areas may improve our understanding of the hydrological cycle (Moore, 2009; Rapaglia et al., 2010) and how low-salinity submarine groundwater discharge (SGD) affects coastal bio-geochemical and physical processes (Moore, 2006).

The detection of offshore low-salinity groundwater reserves can be performed by various methods. Directly, within the framework of drilling programs, through offshore wells allowing for water 
sampling and direct aquifer characterization. Indirectly, by geophysical investigations, such as towed Continuous Electrical Tomography and Airborne Electromagnetic, at least in relatively shallow water depth (e.g., Teatini et al., 2011; Tosi et al., 2011). Such methods are very expensive and are appropriate at local scale. To reduce the extensive field efforts and to simultaneously gain information on groundwater over large spatial scales, many authors used thermal-infrared (TIR) sensors mounted on aircrafts and satellites (Danielescu et al., 2009; Johnson et al. 2008 ; Mallast et al., 2013; Shaban et al., 2005 ). Advanced thermal infrared sensors have the potential to monitor coastal water surface temperature (Xing et al., 2006a; 2006b; 2014 ). Groundwater is commonly less dense than seawater and can form buoyant water "plumes" or diffuse discharges. This method detects temperature contrasts between the inflowing groundwater and surficial waters (river, lake and ocean). The resulting thermal anomalies reveal the potential locations of groundwater discharge over large spatial scales.

With in the Dragon 3 Programme, a cooperation between European Space Agency and Ministry of Science and Technology of the P. R. China, the Project EPHESUS "Ecological and Physical Effects of the Surficial and groundwater exchanges between land and Sea" aims to develop an integrated monitoring approach by satellite products, in situ measurements and hydrological models for an understanding of hydro- morpho- geological processes on coastal areas (Braga et al., 2013b). The proposed approach was tested in the Laizhou Bay and its coastland (Southern Bohai Sea, China) (Figure 1). In this area, the groundwater flow is controlled by various geological factors such as subsoil architecture, fault presence, geomorphology, paleogeography, climate and hydrology. Groundwater properties are characterized by complex variations in both the planar and depth extensions (Wen et al., 2012). Many researches focused their work on the saltwater intrusion in the mainland (e.g., Braga et al., 2013a; Han et al., 2011; Xue et al., 2000), but poor information is still available on the input of fresh water into the sea by SGD.

In order to drive effective in situ hydrogeologic surveys, a preliminary investigation has been performed by remote sensing methods through the analysis of thermal data acquired by the Landsat constellation. Suitable to this investigation is the analysis of Sea Surface Temperature (SST) anomalies. The goal of this study is to evaluate the capability of remote sensing methods to detect thermal anomalies related to SGD as a possible index of the presence of offshore low-salinity groundwater storage. Our basic idea is to search for SGD where the hydraulic, morphologic, and geologic conditions suggest the potential for groundwater leakage from the seabed (Bratton, 2010).

\section{STUDY AREA}

The Bohai Sea is an epicontinental sea with an average depth of $18 \mathrm{~m}$ and maximum depth of about $30 \mathrm{~m}$ at the center. The Laizhou Bay (Figure 1), which form the southern part of the Bohai Sea between the Shandong Peninsula and the Yellow River Delta, is characterized by an inner zone less than $12 \mathrm{~m}$ deep, and an outer zone gently sloping to a $16 \mathrm{~m}$ depth. From the geological point of view, the Laizhou Bay is the result of the high-amplitude glacio-eustatic sea-level rise that followed the Last Glacial Maximum ( LGM), which promoted the formation of a transgressiveregressive system in the epicontinental Bohai shelf. Therefore, during the LGM, when the sea level was about $120 \mathrm{~m}$ below the present position, most of the Bohai Sea was an alluvial plain. Consequently, Pleistocene freshwater has been probably trapped into aquifers beneath the continental shelf and covered by the Holocene layers. Due to the progradation of the Yellow river delta, the Holocene deposition of the Laizhou Bay is thicker in the western side, more than $20 \mathrm{~m}$, and it thins to about $10 \mathrm{~m}$, eastward and north-westward. The tectonics of the area is dominated by the Tanlu fault system, the largest active structure in the eastern region of China. This structure comprises a right lateral strike-slip movement with dip-slip component in the Quaternary and a complex fractural system consisting of related folds and many small normal faults in the central Bohai Sea and the Laizhou bay ( $\mathrm{Li}$ et al., 2010). There is also a good correspondence between the distribution of earthquakes and the pattern of subfaults in the Laizhou Bay and the central Bohai Sea (Li et al., 2010).

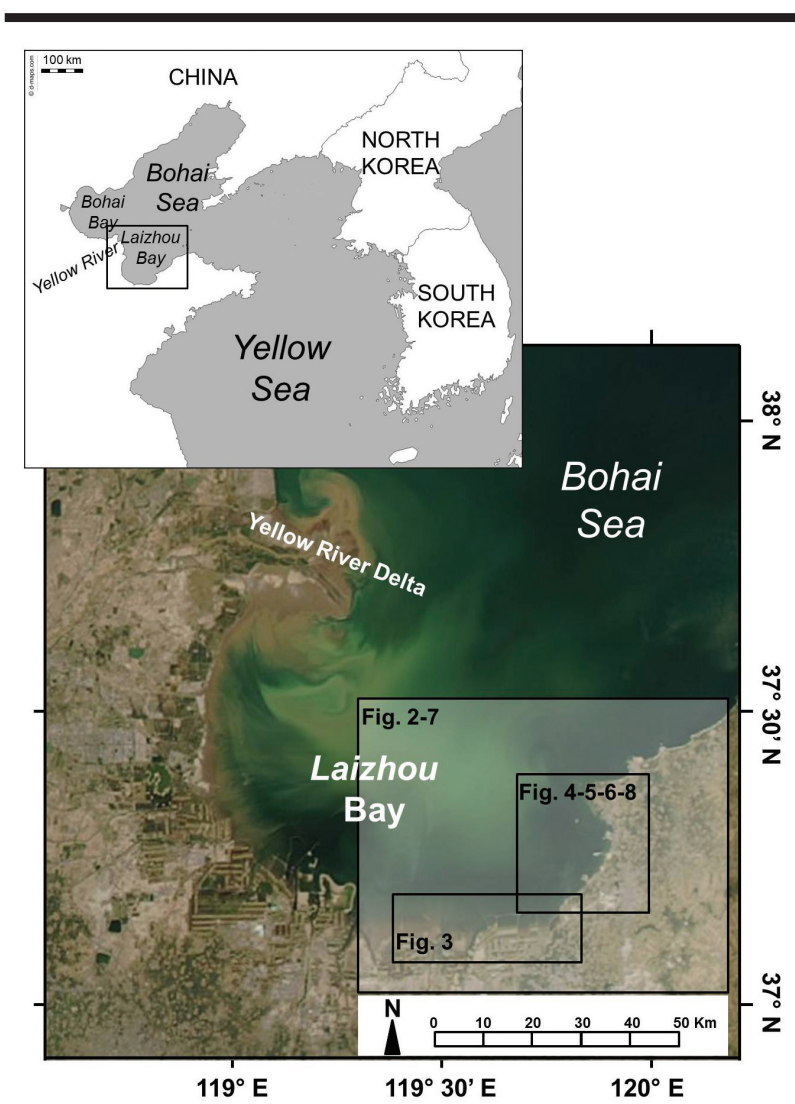

Figure 1. The study area in the Laizhou Bay (Bohai Sea, NE China in the inset). The areas represented in the reported figures are indicated in the highlighted boxes

In the eastern Laizhou Bay, the tidal characteristics can be regarded as irregular semidiurnal tide. The average duration of tide is about $6: 22$ hours and the duration of ebb is about $6: 06$ hours. The difference between Mean High Tide (MHL) and Mean Low Tide (MLT) is $1.01 \mathrm{~m}$. Sea conditions in the area are usually dominated by wind waves, strong and normal wave direc- 
tions are both NNE. Statistically, the mean wave height is $1.3 \mathrm{~m}$ with the averaged period of $4.9 \mathrm{~s}$, and the max wave height is $3.9 \mathrm{~m}$.

\section{DATA AND METHODS}

The hydrogeologic, geomorphologic and geologic features, which can potentially trigger SGD, were analyzed and defined on the basis of information obtained from the literature and open access dataset. SRTM (Jarvis et al., 2008) and bathymetric data ( available from http: // fvcom. smast. umassd. edu ) were used to develop the morphologic model of the study area. Subsoil characteristics (Cheng et al., 2004; Chen et al., 2014; Li and Wang, 1991; Liu et al., 2009) and water analysis (e. g. Han et al., 2011; Han et al., 2012; Ma et al., 2007; Wen et al., 2012) were used to define the hydro-stratigraphic setting. Information on the presence of tectonic lines was obtained from Wang et al. (2006) and Liu et al. (2009).

Several Landsat ETM + band 6.2 ( high gain) data and Landsat 8 OLI band $10(10.9 \mu \mathrm{m})$ data, covering the periods from 2000 to 2003 and from 2013 to 2014 ( cloud cover < $15 \%$ ) respectively, were analyzed. All data were provided with a spatial resolution of $30 \mathrm{~m}$ and resampled using cubic convolution ( USGS, 2011).

The first step in the processing of remotely-sensed imagery was the radiometric correction, which converts the digital numbers (DN) to Top Of Atmosphere ( TOA) Radiance, following the method presented by Chander et al. (2009). The further step was the conversion of TOA radiance to surface radiance values through atmospheric correction according to Coll et al. (2010). Appropriate local values of atmospheric transmissivity, upwelling and downwelling radiances were obtained from the NASA webbased Atmospheric Correction Tool ( http: // atmcorr. gsfc. nasa. gov), that is based on MODTRAN algorithm ( Barsi et al., 2003; $2005)$. In the next step radiance values were converted into brightness temperature in Kelvin and then in Celsius degree, applying the inverse of the Planck function. Lastly, to exclude land pixels, the normalised difference water index ( NDWI) was calculated using the equation $\left(\mathrm{B}_{\text {green }}-\mathrm{B}_{\mathrm{NIR}}\right) /\left(\mathrm{B}_{\text {green }}+\mathrm{B}_{\mathrm{NIR}}\right)$, where $\mathrm{B}_{\text {green }}$ and $\mathrm{B}_{\mathrm{NIR}}$ are the reflectance of green and NIR bands, respectively. On the resulting NDWI image, a threshold equal to 0.3 was applied to distinguish values representing water features ( McFeeters, 1996).

The SST data, finally obtained from the images, represent the skin temperature of the water, i. e., the temperature of the uppermost layer ( $\sim 1 \mathrm{~mm}$ thick) of the sea surface (Fairall et al., 1996). This layer tends to be about $0.1 \mathrm{~K}$ colder than lower water masses due to evaporative heat loss, sensible heat flux, and longwave radiation (Donlon et al., 2002; Wloczyk et al., 2006).

On October, 2014, field investigations were carried out along the shoreline of the eastern Laizhou Bay with the aim of examining the potential SGD from the surficial layer. Water salinity and temperature were measured in surface water samples with a portable salinity meter (Thermo Scientific).

\section{RESULTS AND DISCUSSION}

\section{Conceptual model of the hydro- morpho- geologic setting}

The first step of this work was to identify the structures which could potentially host low-salinity aquifers beneath the sea bottom. This was achieved by developing a conceptual model of the hydro- morpho- geologic setting of the Laizhou Bay and its coastland. All the available information, i. e. morphobathymetric, water table and subsoil data were analyzed.
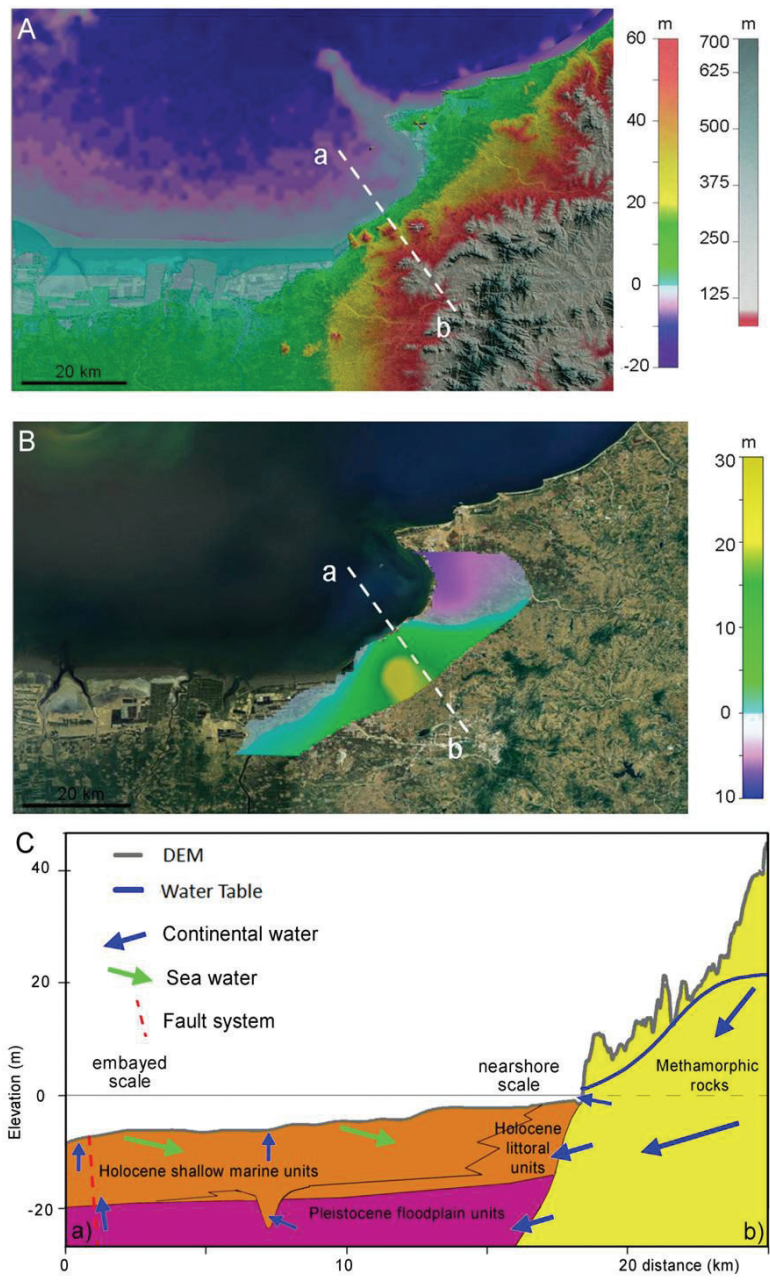

Figure 2. Hydro- geomorphological setting of the Southern and Eastern Laizhou Bay: (A) digital elevation model; ( B ) water table level ( $\mathrm{m}$, above mean sea level); ( C) hydro-morpho- geologic conceptual model along the cross section $\mathrm{a}-\mathrm{b}$

Figure 2A reports the morphologic model (Digital Elevation Model) obtained by mosaicing bathymetric and ground elevation data. It clearly points out a high slope of the mainland due to the presence of the hills and a moderately flat morphology of the seafloor. Figure 2B shows the map of the water table referenced to the mean sea level. Regarding the groundwater level, unfortunately the data available for this study are limited to a small sector of the study area. However it was possible to map the water table and bring to light the presence of a piezometric high which can potentially drive the groundwater flow beneath the sea.

Merging these information with those on subsoil architecture al- 
lowed to outline a conceptual model of the hydro- morphogeologic setting of the Laizhou Bay (Figure 2C). The sketch shows that groundwater can discharge from the seabed at the nearshore and embayment scale because of the piezometric gradient and the subsoil architecture of the Quaternary Units. Low-salinity groundwater can seep along subsoil discontinuities such as incised valley, paleochannels and tectonics faults, i. e., the active TanLu fault zone ( Liu et al., 2009; Wang et al., 2006). This latter has been active during the late Quaternary and it is still the dominant tectonic structure in the Laizhou Bay (Wang et al., 2006). We can therefore hypothesize the seepage of groundwater from the deep aquifer along the shear zone of this fault.

\section{Remote sensing investigation}

This study focuses the investigation on the presence of thermal anomalies in two study areas: Southern and Eastern Laizhou Bay, where groundwater discharges can most likely be expected, as suggested by their hydro-geological setting. SST maps derived from satellite multi-temporal data sets were analyzed to identify variations of the pattern and spatial extent of the groundwater discharges in relation to seasonal and interannual hydrological trend, otherwise difficult to detect by in situ measurements. With the aim of detecting different types of water, satellite images have been selected for different seasons, i. e. when seawater and groundwater are characterised by the largest difference in temperature.

In the Southern Laizhou Bay, TIR images allowed to map several thermal anomalies related to outflows of fresh water plumes with temperatures lower than the minimum values recorded in the seawater of the area. Figure 3A shows that some patchy cold water anomalies, which could be related to a shallow or terrestrial emergence, occur in different days along a $5-\mathrm{km}$ wide shore strip. The presence of some geomorphological features in the intertidal shore could favour the observed anomalies and then, potentially, the groundwater subsurface efflux, (i. e. erosion channels of an upstream located terrestrial spring). This is more evident in very low tide conditions, when such geomorphological features are emerged and visible in the true color satellite image ( Figure 3B).

Extending from the nearshore to the embayment scale, coldwater anomalies are spread in the Eastern Laizhou Bay where there may be a considerable overall SGD input (Figure 4). Cold water could derive from diffuse groundwater discharges as shown by hydrogeological investigation. The high SST in summer makes the temperature difference more marked, thus facilitating the trace of the groundwater seepage pattern. The seepages do not have a direct connection to the coast, which suggests a deeper submarine emergence.

Figure 5 shows a remarkable SST cold spot detected in May 2013 along the eastern Laizhou Bay, a few kilometres off-shore at a water depth of 6-8 m. A visual quality control of this image assessed that this anomalous feature is not due to the presence of clouds and/or their shadows, neither to defective pixels. The SST cold spot has no direct connection to the coast; therefore its origin is probably submarine as groundwater likely seeps from the sea bottom where the confined aquifer is locally exposed. The slightly smaller SST values are the effect of vertical mixing and heat exchange between the seawater and the discharging and ascending groundwater.
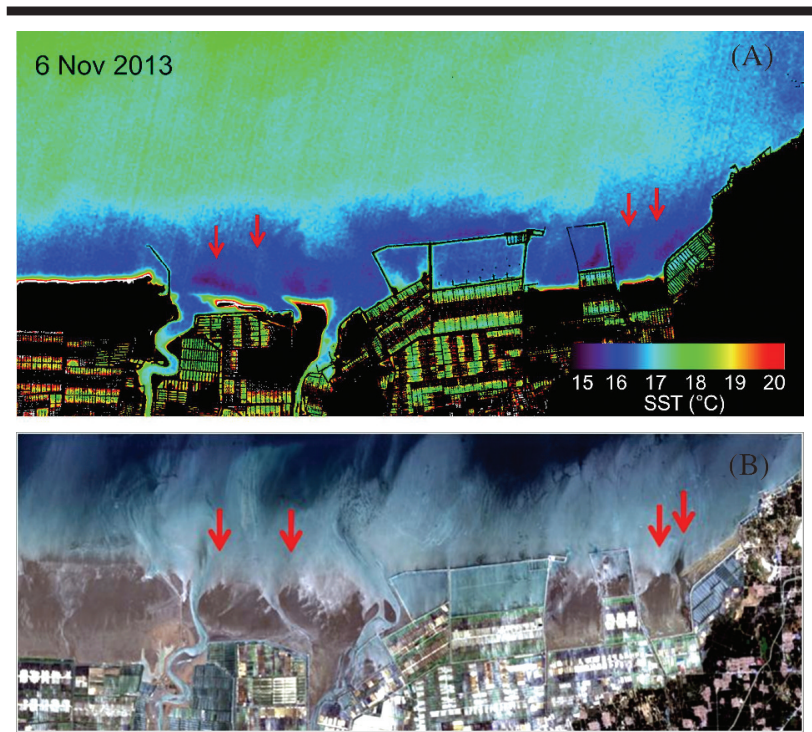

Figure 3. (A) Temperature anomalies are identified along a 5-km wide shore strip in the Southern Laizhou Bay. Red arrows indicate the location of cold anomalies. (B) Real-colour images of the coastal strip with the same red arrows as in the thermal image

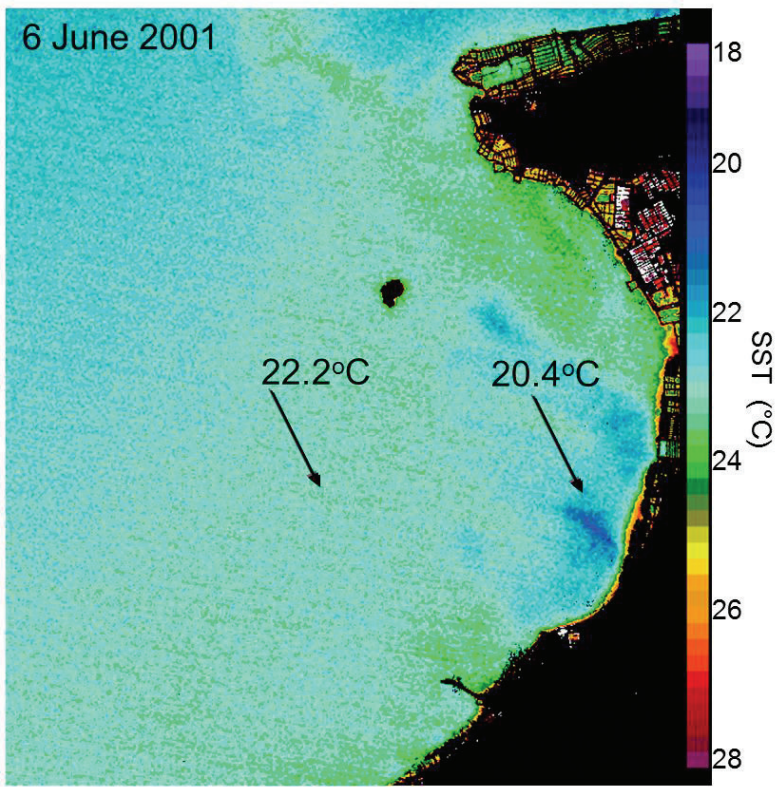

Figure 4. Cold water patches observed at the eastern Laizhou Bay in summer 2001 


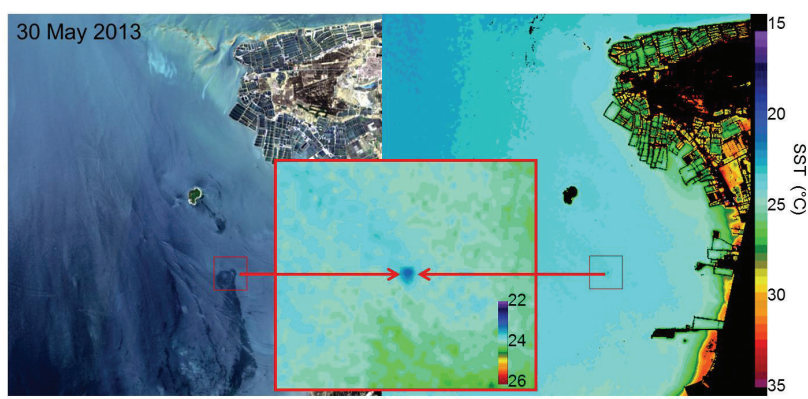

Figure 5. Anomaly in SST at the eastern Laizhou Bay showing a possible SGD as a cold spring in summer

As shown in Figure 6, the extensive anthropogenic pressure on the nearshore area has significantly changed the hydro-geomorphologic settings of Eastern Laizhou Bay over the last 10 years. Landuse by urbanization and occupation of the coastline by human activities and constructions has likely impacted groundwater resources and discharge pathways. Urban development and aquaculture also cause a significant reduction of groundwater resources.

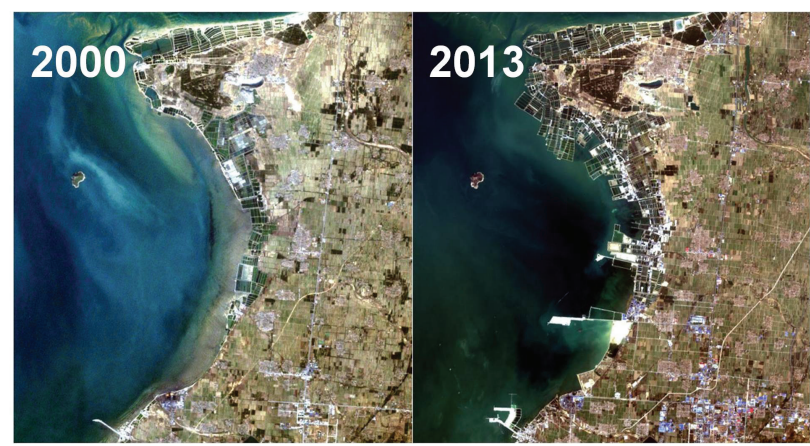

Figure 6. Land-cover change in the Southern Laizhou bay from year 2000 (left) to year 2013 ( right)

Figure 7 shows the presence of floating ice in the Eastern Laizhou Bay. Severe weather conditions occurred with snow in the land and ice in coastal waters. The ice formation on the coast is facilitated by freshwater of Yellow River, which drifts into Laizhou Bay (Zhang et al., 2013). The freshwater contribution from groundwater discharge could also contribute to the ice formation in this part of the bay. The SST map, obtained by the thermal band of the Landsat image acquired on 12 January, 2003 ( Figure 7 ), clearly shows the potential coastal inputs of groundwater, marked by a relatively warmer temperature in the Eastern Laizhou Bay. In fact, it is reasonable to assume that in winter, SGD is relatively warmer than seawater at input. These patterns are consistent with the location of the cold SST anomalies detected in summer.

\section{In-situ investigation}

Figure 8 and Table 1 show the results of a water salinity survey carried out along the Laizhou shoreline in the middle October, 2014.

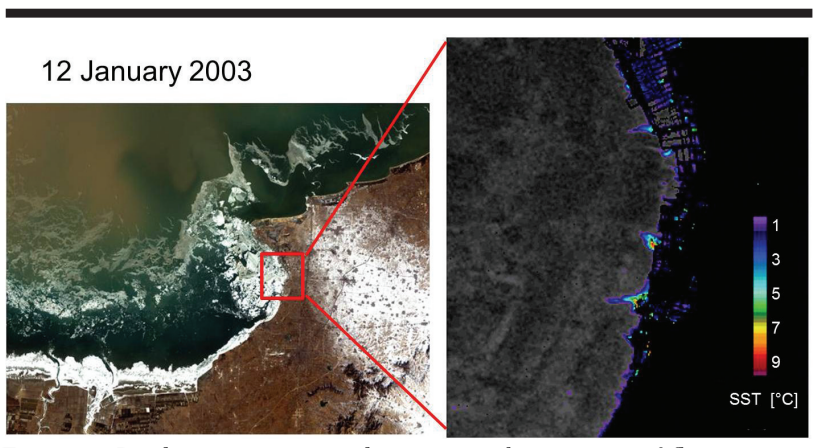

Figure 7. Landsat image acquired in winter: the presence of floating ice is evident on the RGB combination (left); relatively warmer waters near the coast might be due to SGD in winter in the Eastern Laizhou Bay as shown in the SST map (right)

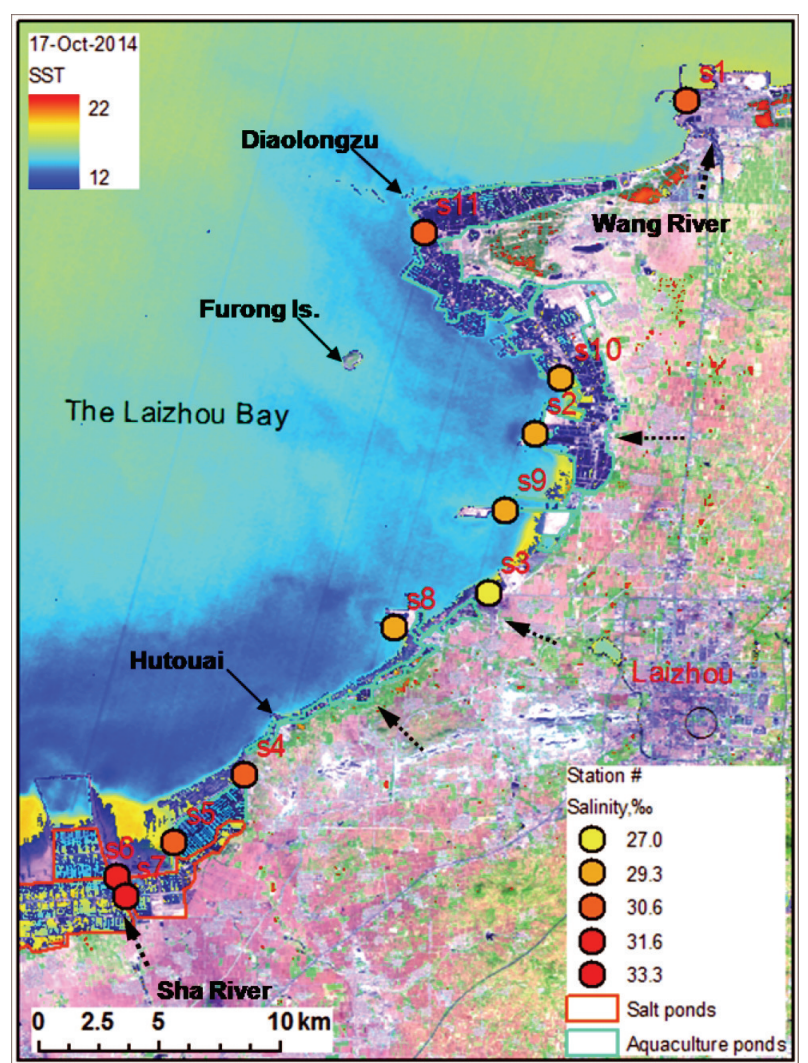

Figure 8. Results of the in-situ investigation on the water salinity carried out along the Laizhou Bay in October 2014. The dotted arrows show the outlet sites of unnamed small streams

Salinity at the study area (stations \# s2, s3, s8, s9 and s10) is relatively lower than in the nearby regions (\# s1, s4, s5, s6, s7 and s11). The coast from Diaolongzu ( 111$)$ to Hutouai (s4) is characterized by sandy beaches, which favour the discharge of fresh waters in the shallow bay. As shown at station \#s3, salinity 
of sea water can be as low as $18 \%$ at the low tidal level (Figure $9 \mathrm{~A})$; this salinity value is much lower than that measured at maximum high tide $(27 \%$ ) , consistently with a possible smaller SGD when a smaller pressure (that is a smaller water level) occurs. The variations in salinity with water level are in agreement with the modelling results on SGD in the region ( $\mathrm{Bu}$ et al., 2013). Surficial fresh water discharges from rivers or streams may also contribute to the low temperature and low salinity; however, this is not likely the primary reason. For example, larger discharges from larger rivers (the Sha River and the Wang River) didn't cause lower salinity than the unnamed very small streams with smaller discharges ( see Figure 8) ; and, surficial river discharge does not likely cause an offshore spot with low temperature ( see Figure 5 ). Wang et al. (2015) reported significant signal of huge SGD in the Laizhou Bay which is close to the Yellow River runoff ( Figure 1).

Table 1. In-situ measured water temperature and sanility

\begin{tabular}{cccccc}
\hline \hline st. & $\begin{array}{c}\text { Date } \\
(\text { YYYYMMDD })\end{array}$ & $\begin{array}{c}\text { Time } \\
\text { HH }: \text { MM })\end{array}$ & T, ${ }^{\circ} \mathrm{C}$ & Sali., \%o & $\begin{array}{c}\text { Tidal level, } \\
\mathrm{m}\end{array}$ \\
\hline s1 & 20141016 & $11: 00$ & 17.90 & 30.56 & 0.5 \\
s2 & 20141016 & $12: 00$ & 16.60 & 28.21 & 0.6 \\
s3 & 20141016 & $14: 30$ & 22.40 & 27.00 & 0.9 \\
s3 & 20141017 & $10: 30$ & 16.90 & 17.91 & 0.5 \\
s4 & 20141016 & $15: 56$ & 23.30 & $30.65 *$ & 1.6 \\
s5 & 20141016 & $16: 23$ & 21.20 & 30.26 & 1.7 \\
s6 & 20141016 & $16: 45$ & 20.20 & 31.55 & 1.7 \\
s7 & 20141016 & $16: 50$ & 17.60 & 33.27 & 1.8 \\
s8 & 20141017 & $10: 00$ & 13.80 & 29.28 & 0.6 \\
s9 & 20141017 & $11: 10$ & 13.90 & 29.27 & 0.5 \\
s10 & 20141017 & $12: 10$ & 19.60 & 28.60 & 0.5 \\
s11 & 20141017 & $14: 15$ & 16.90 & 30.20 & 0.7 \\
\hline
\end{tabular}

* The water salinity in wells is $27 \%$.

Piezometric data in a well at station \#s4 located on a rocky coast (Figure 9B) revealed that sea level is generally higher than local water table. As shown in Figure 8, aquaculture ponds (AP) in this area used pumped sea water, and the salinity in aquaculture ponds were the same as the coastal water. So, low salinity of sea water and its variations with tide can not be caused by the discharge of APs. We then speculate that the low temperature observed from satellite images (Figure 4 and 5 ) was associated with the discharge of subsurface fresh water.

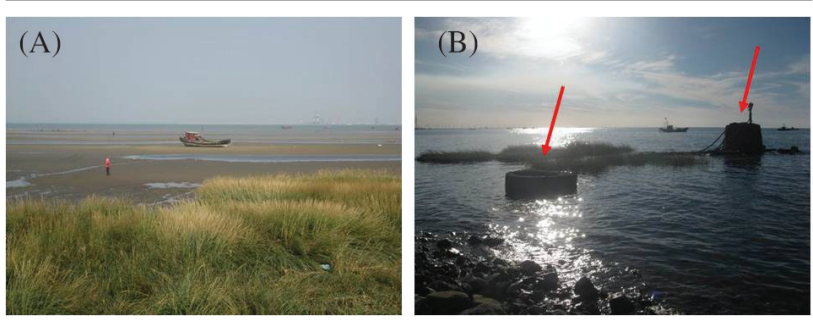

Figure 9. In-situ photo: (A) tidal flat at low tide ( site \#s3'); (B) wells at shoreline (indicated by arrows)
During the field surveys, aggregations of green macroalgae ( green tides) ( Figure 10) were observed at the sites characterized by the discharges of groundwater. The occurrence of macroalgal blooms in this study area might be also a biological index to the enhanced nutrient input by groundwater discharge, which although was not fully considered in the water quality monitoring and management in the past in China (Xing et al., 2015a, b; Xing and $\mathrm{Hu}, 2016$ ).
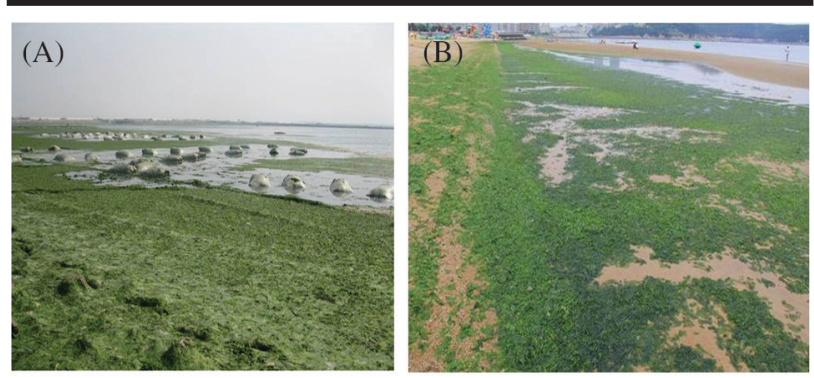

Figure 10. Macroalgal blooms observed during field surveys along the north coast of Shandong Peninsula in 2014: (A) the eastern Laizhou Bay; (B) the Gold Sand Bay

\section{SUMMARY AND CONCLUSIONS}

Many researches focused on the saltwater intrusion in the Laizhou Bay coastland, but poor information is still available about the input of fresh water into the sea by SGD.

In this study, we observed SST anomalies in the Southern and Eastern Laizhou Bay during summer and winter seasons. The interpretation of these features, also considering the morpho-hydrogeologic setting of the areas where they occur, showed that SST anomalies are not related to long-shore circulation or river discharge and therefore may be associated to local SGD.

Our results suggest that the analysis of TIR images can conveniently address hydrogeological field investigations permitting to map features, both localized and diffuse, such as gradients and anomalies associated to submarine groundwater seepage.

In addition, the satellite multi-temporal data sets allowed to identify variations of the pattern and spatial extent of the SGD in relation to seasonal and interannual hydrological trends, otherwise difficult to detect by in situ measurements.

Although the use of remote sensing cannot replace direct investigations, it is an efficient tool for driving field activities, like samplings and geophysical surveys for a detailed SGD investigation. Once a general overview of the area and a conceptual model are acquired, other specific investigations in the areas of interest can be performed to calibrate the remote sensing outcomes and validate the SGD occurrences: for example Radon and Radium isotope assessment and geophysical surveys.

Our research shows that combining hydro-morphological investigations and remote sensing data permits to describe the relationships between land and coastal hydrology and to identify mediumto-small scale features.

This approach can be helpful to address studies on transport and storage in the coastal area. Possible future water scarcity due to overexploitation, pollution, and climatic changes will require the identification of at least temporary alternative fresh or low-sa- 
linity water supplies. For its intrinsic complexity Laizhou Bay is clearly a key site to test appropriate methodologies for this aim. Coupling and interaction between groundwater and surface water in on-shore and off-shore coastal zones is becoming even more evident. For this reason we point out the need of future oceanographic and groundwater flow modelling along with long-term monitoring of processes associated with the suspected SGD in the Laizhou Bay.

\section{ACKNOWLEDGMENTS}

This work was supported by the Strategic Priority Research Program of the Chinese Academy of Sciences (Grant No. XDA11020305), the External Cooperation Program of the Chinese Academy of Sciences (Grant No. GJHZ1207), and the YIC-CAS (China) and ISMAR-CNR (Italy) joint research programme. Landsat ETM and OLI satellite data are provided under the framework of ESA-NRSCC dragon-3 program. SRTM data $\mathrm{V} 4$, the USGS/NASA, are provided from the International Centre for Tropical Agriculture ( CIAT).

\section{LITERATURE CITED}

Barsi, J. A.; Barker, J. L., and Schott, J. R., 2003. An atmospheric correction parameter calculator for a single thermal band earth-sensing instrument. Proceedings of Geoscience and Remote Sensing Symposium, IGARSS03 (Centre de Congress Pierre Bandis Toulouse ), 2003 IEEE International, 5, 3014 -3016 .

Barsi, J. A.; Schott, J. R.; Palluconi, D. F., and Hook, S. J., 2005. Validation of a web based atmospheric correction tool for single thermal band instruments. Proceedings of the SPIE, Earth Observing Systems $X$ (San Diego, California, USA ) , 58820E.

Braga, F.; Donnici, S.; Teatini, P.; Tosi, L.; Zaggia, L.; Gao, X.; Shi, P.; Tang, C.; Xing, Q.; Wang, D., and Wen, X., 2013a. Salt contamination process in coastal aquifers of Yantai, China, and Venice. Proceedings of Italy - China: An Ancient Cultural Heritage and the Challenge for Future Development. (Adriana Galvani), 197-203.

Braga, F.; Xing, Q.; Lou, M.; Shi, P.; Teatini, P.; Tosi, L.; Zaggia, L.; Donnici, S.; Bresciani, M.; Pascucci, S.; Li, S.; Gao, Z.; Yu, D.; Tang, C.; Wang, D., and Sun, Q., 2013b. EPHESUS: remote sensing for coastal processes in southern Bohai Sea, China. Proceedings of Italy-China: An Ancient Cultural Heritage and the Challenge for Future Development (Adriana Galvani), 189-196.

Bratton, J. F., 2010. The three scales of submarine groundwater flow and discharge across passive continental margins. The Journal of Geology, 118(5) , 565-575.

Bu, Q.; Li, F.; Chen, X., and Lin, L., 2013. Identification and quantification of submarine groundwater discharge along the east coast of the Laizhou Bay. Marine Sciences, 37(11), 74 -78 .

Chander, G.; Markham, B. L., and Helder, D. L., 2009. Summary of current radiometric calibration coefficients for Landsat MSS, TM, ETM+, and EO-1 ALI sensors. Remote Sensing of Environment, 113 ( 5) , 893-903.

Chen, Q.; Lu, Q.; Song, Z.; Chen, P.; Cui, Y.; Zhang, R., and Liu, J., 2014. The levels of fluorine in the sediments of the aquifer and their significance for fluorosis in coastal region of Laizhou Bay, China. Environmental Earth Sciences, 71 (10), 4513-4522.

Cheng, J.; Chen, C., and Ji, M., 2004. Determination of aquifer roof extending under the sea from variable-density flow modelling of groundwater response to tidal loading: case study of the Jahe River Basin, Shandong Province, China. Hydrogeology Journal, 12(4), 408-423.

Coll, C.; Galve, J. M.; Sanchez, J. M., and Caselles, V., 2010. Validation of Landsat-7/ETM + thermal-band calibration and atmospheric correction with ground-based measurements. Geoscience and Remote Sensing, IEEE Transactions on, 48(1), $547-555$.

Danielescu, S.; MacQuarrie, K. T. B., and Faux, R. N., 2009. The integration of thermal infrared imaging, discharge measurements and numerical simulation to quantify the relative contributions of freshwater inflows to small estuaries in Atlantic Canada. Hydrological Processes, 23 ( 20 ), 2847 -2859 .

Donlon, C. J.; Minnett, P. J.; Gentemann, C.; Nightingale, T. J.; Barton, I. J.; Ward, B., and Murray, M. J., 2002. Toward improved validation of satellite sea surface skin temperature measurements for climate research. Journal of Climate, 15(4), 353-369.

Fairall, C. W.; Bradley, E. F.; Rogers, D. P.; Edson, J. B., and Young, G. S., 1996. Bulk parameterization of air-sea fluxes for tropical ocean-global atmosphere coupled-ocean atmosphere response experiment. Journal of Geophysical Research: Oceans (1978-2012), 101( C2 ), 3747-3764.

Han, D.; Kohfahl, C.; Song, X.; Xiao, G., and Yang, J., 2011. Geochemical and isotopic evidence for palaeo-seawater intrusion into the south coast aquifer of Laizhou Bay, China. Applied Geochemistry, 26(5) , 863-883.

IPCC, 2014. Climate change 2014 synthesis report. http: // digital. library. unt. edu/ark :/67531/metadc501464/.

Jackson, R. B.; Carpenter, S. R.; Dahm, C. N.; McKnight, D. M.; Naiman, R. J.; Postel, S. L., and Running, S. W., 2001. Water in a changing world. Ecological Applications, 11 (4) , 1027-1045.

Jarvis, A.; Reuter, H. I.; Nelson, A., and Guevara, E., 2008. Hole-filled seamless SRTM data V4, International Centre for Tropical Agriculture (CIAT). http:// srtm. csi. cgiar. org.

Johnson, A. G.; Glenn, C. R.; Burnett, W. C.; Peterson, R. N., and Lucey, P. G., 2008. Aerial infrared imaging reveals large nutrient-rich groundwater inputs to the ocean. Geophysical Research Letters, 35(15), 15601-15606.

Li, C. and Wang, P., 1991. Stratigraphy of the late Quaternary barrier-lagoon depositional systems along the coast of China. Sedimentary Geology, 72(3), 189-200.

Li, X. S.; Zhao, Y. X.; Liu, B. H.; Liu, C. G.; Pei, Y. L.; Han, G. Z., and Hua, Q. F., 2010. Structural deformation and fault activity of the Tan-Lu fault zone in the Bohai Sea since the late Pleistocene. Chinese Science Bulletin, 55(18), $1908-1916$

Liu, J.; Saito, Y.; Wang, H.; Zhou, L., and Yang, Z., 2009. Stratigraphic development during the Late Pleistocene and Holocene offshore of the Yellow River delta, Bohai Sea. Journal of Asian Earth Sciences, 36(4), 318-331.

Ma, F.; Yang, Y. S.; Yuan, R.; Cai, Z., and Pan, S., 2007. Study of shallow groundwater quality evolution under saline in- 
trusion with environmental isotopes and geochemistry. Environmental Geology, 51 (6) , 1009-1017.

Mallast, U.; Siebert, C.; Wagner, B.; Sauter, M.; Gloaguen, R.; Geyer, S., and Merz, R., 2013. Localisation and temporal variability of groundwater discharge into the Dead Sea using thermal satellite data. Environmental Earth Sciences, 69(2), 587-603.

McFeeters, S. K., 1996. The use of the normalized difference water index (NDWI) in the delineation of open water features. International Journal of Remote Sensing, 17 ( 7 ), 1425 -1432 .

Moore, W. S., 2006. The role of submarine groundwater discharge in coastal biogeochemistry. Journal of Geochemical Exploration, 88(1), 389-393.

Plan Bleu, 2008. Climate change and energy in the Mediterranean. Sophia Antipolis: Plan Bleu Regional Activity Centre. http: // planbleu. org/sites/default/files/publications/changement_clim_energie_med_en.pdf

Post, V.E.; Groen, J.; Kooi, H.; Person, M.; Ge, S., and Edmunds, W. M., 2013. Offshore fresh groundwater reserves as a global phenomenon. Nature, 504(7478) , 71-78.

Rao, A. M. F. and Charette, M. A., 2012. Benthic Nitrogen Fixation in an Eutrophic Estuary Affected by Groundwater Discharge. Journal of Coastal Research, 28(2) , 477-485.

Rapaglia, J.; Di, S. E.; Bokuniewicz, H.; Zuppi, G. M.; Zaggia, L.; Galgaro, A., and Beck, A., 2010. Groundwater connections under a barrier beach: A case study in the Venice Lagoon. Continental Shelf Research, 30(2), 119-126.

Shaban, A.; Khawalie, M.; Abdallah, C., and Faour, G., 2005. Geologic controls of submarine groundwater discharge: application of remote sensing to north Lebanon. Environmental Geology, 47(4), 512-522.

Teatini, P.; Tosi, L.; Viezzoli, A.; Baradello, L.; Zecchin, M., and Silvestri, S., 2011. Understanding the hydrogeology of the Venice Lagoon subsurface with airborne electromagnetics. Journal of Hydrology, 411 (3) , 342-354.

Tosi, L.; Baradello, L.; Teatini, P.; Zecchin, M.; Bonardi, M.; Shi, P.; Tang, C.; Li, F.; Brancolini, G.; Chen, Q.; Chiozzotto, B.; Frankenfield, J.; Giada, M.; Liu, D.; Nieto, D.; Rizzetto, F.; Sheng, Y.; Xiao, Y., and Zhou, D., 2011. Combined continuous electrical tomography and very high resolution seismic surveys to assess continental and marine groundwater mixing. Bollettino di Geofisica Teorica ed Applicata, 52(4), 585-594.

USGS, 2011. Landsat ETM + product description from the earth resources observation and science (EROS) Center. http: // eros. usgs. gov/\#/Find _ Data/ Products _ and _ Data Available/ETM.

Wang, X.; Li, H.; Jiao, J. J.; Barry, D. A.; Li, L.; Luo, X.; Wang, C.; Wan, L.; Wang, X.; Jiang, X.; Man, Q., and
Qu, W., 2015. Submarine fresh groundwater discharge into Laizhou Bay comparable to the Yellow River flux. Scientific Reports, 5, 8814.

Wang, Z. C.; Deng, Q. D.; Du, X. S.; Chao, H. T.; Wu, Z. Q.; Xiao, L. X., and Li, C. C., 2006. Active fault survey on the Tanlu fault zone in Laizhou Bay. Acta Seismologica Sinica, $19,530-541$

Wen, X.; Diao, M.; Wang, D., and Gao, M., 2012. Hydrochemical characteristics and salinization processes of groundwater in the shallow aquifer of eastern Laizhou Bay, China. Hydrological Processes, 26(15), 2322-2332.

Wloczyk, C.; Richter, R.; Borg, E., and Neubert, W., 2006. Sea and lake surface temperature retrieval from Landsat thermal data in Northern Germany. International Journal of Remote Sensing, 27(12), 2489-2502.

Xing, Q.; Chen, C., and Shi, P., 2006a. Method of integrating Landsat -5 and Landsat -7 data to retrieve sea surface temperature in coastal waters on the basis of local empirical algorithm. Ocean Science Journal, 41(2), 97-104.

Xing, Q.; Chen, C.; Shi, P., and Yang, J., $2006 \mathrm{~b}$. Atmospheric correction of Landsat data for the retrieval of sea surface temperature in coastal waters. Acta Oceanologica Sinica, 25(3), 25-34.

Xing, Q.; Lou, M.; Zhang, J.; Li, Z.; Nin, J., and Gao, Z., 2014. Radiometric cross-calibration of Tiangong-1 and MODIS infrared bands and applications in monitoring coastal sea surface temperature. Journal of Remote Sensing, 18 (Z1), 68-73.

Xing, Q.; Hu, C.; Tang, D.; Tian, L.; Tang, S.; Wang, X. H.; Lou, M., and Gao, X., 2015a. World's largest macroalgal blooms altered phytoplankton biomass in summer in the Yellow Sea: satellite observations. Remote Sensing, 7, 12297 -12313 .

Xing, Q.; Tosi, L.; Braga, F.; Gao, X., and Gao, M., 2015 b. Interpreting the progressive eutrophication behind the world's largest macroalgal blooms with water quality and ocean color data. Natural Hazards, 78, 7-21.

Xing, Q. and Hu, C., 2016. Mapping macroalgal blooms in the Yellow Sea and East China Sea using HJ-1 and Landsat data: Application of a virtual baseline reflectance height technique. Remote sensing of Environment, 178, 113-126.

Xue, Y.; Wu, J.; Ye, S., and Zhang, Y., 2000. Hydrogeological and hydrogeochemical studies for salt water intrusion on the south coast of Laizhou Bay, China. Groundwater, 38(1), 38-45.

Zhang, X. L.; Zhang, Z. H.; Xu, Z. J.; Li, G.; Sun, Q., and Hou, X. J., 2013. Sea ice disasters and their impacts since 2000 in Laizhou Bay of Bohai Sea, China. Natural hazards, 65 (1), 27-40. 